NOTAS

\title{
LOS CIEN AÑOS DEL DOCTOR MOREAU
}

Jaime Perales *

$E_{n}$ el año 1913 se filmó L'Ile de Epouvante, primer película influenciada por la novela del escritor inglés Herbert George Wells, La isla del doctor Moreau. Al cumplirse cien años de haberse publicado la novela del célebre escritor, y cincuenta de la muerte de Wells, el cine le ha hecho un homenaje filmando la tercera versión en lengua inglesa de la formidable y extraña aventura. En ésta es Marlon Brando quien personifica al torturado científico que realiza experimentos con animales vivos convirtiéndolos en desagradables criaturas.

La isla del doctor Moreau fue escrita apresuradamente por un hombre de treinta años que ya se había ganado el calificativo de 'genio'. No era excesivo, un año antes del Doctor Moreau había publicado las novelas La máquina del tiempo, La visita maravillosa, el libro de cuentos

* Egresado del ITAM, realiza estudios de postgrado en Georgetown University.
El bacilo robado, y tenía el borrador de las novelas El hombre invisible y Las ruedas de la suerte. De igual manera, antes de conocido como escritor de ficciones, había publicado, a los veintisiete años, el volumen Libro de texto de Biología y dos artículos especializados. Lo más interesante es que, entre todos estos libros, Wells se vanagloriaba de $L a$ isla del doctor Moreau como su libro predilecto, según lo expresara en una entrevista con un magazine londinense.

Sin embargo, la novela desgraciadamente nunca ha sido respetada en su totalidad por el cine. Wells, un hombre interesado por la pantalla grande, al ver la versión de los Estudios Universal, protagonizada por Charles Laughton, La isla de las almas perdidas en 1932, se quejó por el tratamiento que se le dio al personaje de Moreau, explotando simplemente la imagen lúgubre y maniática del inmortal doctor. Para Wells, Moreau era más que un científico 
NOTAS

desquiciado, su personalidad representaba la curiosidad de la ciencia de la época por observar la evolución de la humanidad desde una perspectiva artificial. Wells se basó en dos artículos científicos escritos por él mismo -"Los límites de la plasticidad individual" (1895) y "La evolución humana como un proceso artificial", publicado un año despuéspara escribir el capítulo de la novela "Moreau se justifica", texto importante para entender la moralidad del personaje de Wells y las inquietudes científicas de la época con respecto al proceso evolutivo del hombre; que por cierto, el cine ha olvidado parcialmente.

Igualmente, Wells leyó un ensayo escrito en 1893 por su profesor $y$ mentor, el gran biólogo inglés Thomas Henry Huxley, titulado "Evolución y ética", en el cual la tesis principal versaba sobre la evolución de las especies como un proceso cruel y arbitrario, mientras la ética sólo podía avanzar en un proceso inverso. Para Huxley, el hombre seguía conservando las cualidades del mono y del tigre, las cuales eran virtudes naturales individuales y que, sin embargo, en la sociedad eran vistas como defectos. Wells al escribir La isla del doctor Moreau tomó muy en cuenta la perspectiva del ensayo de Huxley, ya que la novela es una argumentación moral y científica sobre la pretendida hu- manidad del hombre y la supuesta bestialidad de los animales.

La respuesta a la novela de Wells, a finales del siglo XIX, no se hizo esperar, el Times la trató de 'morbosa', 'perversa' y 'sensacionalista'; The Athenaeum le dedicó dos tercios de una columna denunciándola como una 'pieza de arte despreciable'; el Speaker reprochó a la novela ofender 'la decencia' y el 'sentido común' de la sociedad. Otras críticas se centraron en la inverosimilitud científica de alguien que pueda 'manufacturar monstruos' dentro de las posibilidades de la biología, como fue el caso del colega de Wells, el biólogo Peter Chalmers Mitchel. Wells, sorprendido, se defendió de sus detractores un tanto inocentemente, tomando como referencia un artículo publicado por una revista médica de la época en el que se intentaba probar que se podían hacer injertos de conejo en un ser humano. Sin embargo, la verdadera falta de visión del periodismo de la época fue que la mayoría de las críticas omitieron cualquier virtud literaria tanto de la novela como del propio argumento y se centraron en los problemas morales o científicos del libro. La única crítica con la que estuvo satisfecho el autor inglés fue la de un periodista de The Guardian que hablaba de la novela como una parodia de Dios y sus hijos imperfectos, a quienes les es imposible 
ajustarse al mandato de las leyes. La última versión cinematográfica de Moreau toma muy en cuenta la idea del reseñista de The Guardian.

El tratamiento de sádico maniático que el cine ha dado a Moreau inicia con la versión francesa de 1913, se repite en la caracterización de Charles Laughton en 1932, continúa con Burt Lancaster en la versión de 1977 y concluye con el personaje encarnado por Marlon Brando en 1996, el cual presenta gran similitud con el de Kurtz en Apocalipsis. (Lo cual no es de extrañar ya que la novela de Wells influyó en su amigo Joseph Conrad, autor de El corazón de las tinieblas (1898), novela en la que Francis Ford Coppola se basó para realizar dicha película.)

Otra diferencia importante entre la novela y el cine es que Moreau realizaba vivisección con animales, no cirugía genética entre animales y hombres: Moreau no utilizaba a seres humanos en sus experimentos, como muestra la segunda versión cinematográfica. Igualmente, el triángulo amoroso, inevitable en Hollywood, aparece de una forma $u$ otra en todas las versiones, mientras que en la novela hay pálidas referencias al elemento femenino. Asimismo, existe una especie de maldición, originada igualmente por Hollywood, para confundir el nombre del antagonista de Moreau. Edward Prendrick, el náu- frago narrador de toda la novela, pasa a ser Edward Parker en la primera versión, Edward Bradock en la segunda y Edward Douglas en la última.

A pesar de la falta de comprensión por parte del cine, la influencia de Moreau en el 'subsconsciente literario' ha sido vasto e importante. Se ha mencionado, entre otros, a autores como Joseph Conrad, Edgard Rice Burroughs, George Bernard Shaw, Aldous Huxley, George Orwell, Anthony West y William Golding como influenciados por Wells. Por su parte, Robert M. Philmus en su edición crítica del libro The Island of Doctor Moreau a Variourum Text (1993), encuentra un sinnúmero de "hijos literarios": The Island of Professor Menu de James Sullivan (1896); The Prots de Dudbroque Montague (pseudónimo) (1903); Le Docteur Lerne, Sous Dieu (1908) de Aurice Renard; Nothing Ever Happens (1927) de Maurice Lincoln; Kontrol (1928) de Edmund Snell; The Monster Men (1929) de Edgard Rice Burroughs; The Croquet Player (1937) del propio Wells; la versión femenina de Moreau de Joseph Nesbadba en su Doctor Moreau's Other Island (1971); The White Otters of Chilhood (1982) de Michel Bishop; el Moreau á la "Norman $\mathrm{O}$. Brown" en la versión de Brian Aldiss Moreau's Other 


\section{NOTAS}

Island (1980); The Island of Doctor Death and Other Stories (1980) de Gene Wolfe; y la novela de Shepard Lucius sobre el encuentro entre un veterano de Vietnam en una isla del Paraguay con el llamado "ángel de la muerte" de Auschwitz, Mengele (1987).

Finalmente, el autor menciona a dos narradores latinoamericanos en los que la influencia de la novela del escritor inglés es menos directa, pero no por ello menos importante: $X Y Z$ (1934) del peruano Clemente Palma, en la que el protagonista Rolland Poe, estudiante de la Universidad de los Ángeles, se encuentra obsesionado por crear vida artificial; y La invención de Morel (1940) de Adolfo Bioy Casares, en la cual un científico llamado Morel crea un mundo artificial a través de proyecciones holográficas. La novela es mencionada como una heredera latinoamericana de Moreau en el famoso prólogo que la acompaña, escrito por el más entusiasta y conocido admirador latinoamericano de H.G. Wells: Jorge Luis Borges. 